\title{
Carbon Dynamics under Different Land-Use Systems of Nandipura Mini-Watershed of Chikkamagaluru District, Karnataka, India
}

\author{
Jahnavi Katti $^{1^{*}}$, K. T. Gurumurthy ${ }^{1}$, D. Ravikumar ${ }^{2}$ and T. S. Vageesh ${ }^{1}$ \\ ${ }^{1}$ Department of Soil Science \& Agriculture Chemistry, UAHS, Shivamogga, India \\ ${ }^{2}$ Department of Soil Science \& Agriculture Chemistry, COA, Ponnampet, India \\ *Corresponding author
}

\begin{abstract}
A B S T R A C T
\section{Keywords}

Carbon fractions,

Carbon stock,

Land-use systems,

Mini-watershed,

Soil depth

Article Info

Accepted:

25 September 2020

Available Online:

10 October 2020

Assessment of carbon fraction was undertaken in Nandipura mini-watershed area under different land-use systems. Eight land-use systems were selected viz; agricultural system (maize, ragi and groundnut), horticulture system (arecanut, coconut and pomegranate), fallow land and scrubby land for the study of dynamics of carbon. Among the different land-use systems, horticultural land use systems recorded significantly higher potassium dichromate oxidizable carbon (PDOC), potassium permanganate oxidizable carbon (PPOC), Cold water extractable carbon (CWEC), soil microbial biomass carbon (SMBC), Total organic carbon (TOC), Total inorganic carbon (TIC) and Total Carbon (TC) at three depths of soil $(0-20 \mathrm{~cm}, 20-40 \mathrm{~cm}$ and 40-60 cm) followed by agricultural land-use system. Significantly higher carbon stock was recoded under arecanut land-use system $\left(30.95 \mathrm{t} \mathrm{C} \mathrm{ha}^{-1}\right)$ at surface depth and least carbon stock was recorded under maize land-use system $\left(17.29 \mathrm{t} \mathrm{C} \mathrm{ha}^{-1}\right)$. Similar trend was observed at subsurface layers.
\end{abstract}

\section{Introduction}

Soil organic matter (SOM) is of fundamental importance in maintaining soil fertility. A good farming practice can decrease $\mathrm{CO}_{2}$ evolution into the atmosphere and enhance soil fertility and productivity. It is more important in tropical and subtropical regions where soils are inherently low in organic carbon content and the production system is fragile. Following the unprecedented expansion and intensification of agriculture in India, there are clear evidence of the decline in the soil organic carbon (SOC) contents in many soils on one hand, while on the other hand good farming practices such as balanced fertilization and addition of crop residues either maintain or result in build-up or depletion of soil organic carbon (SOC) stock (Swarup et al., 2000). The restoration of SOC in arable lands represents a potential sink for atmospheric $\mathrm{CO}_{2}$. The soil has a significant role in the carbon cycle. The carbon pools are components of the ecosystem that can either accumulate or release carbon.

Cultivation reduces soil carbon content and changes the distribution and stability of soil 
aggregates. Different land-use systems influence soil aggregation, aggregate stability and overall soil health. Land-use changes have a great influence on many soil physical and chemical properties, mostly soil organic matter affecting its quality attributes and fertility. Organic matter is a key factor in improving the overall productivity of the cropping system.

\section{Materials and Methods}

Nandipura mini-watershed comes under Mugli sub-watershed of Tarikere taluk, Chikkamagaluru district. The mini-watershed is $40 \mathrm{~km}$ away from Chikkamgaluru district. Soil samples were collected under different land-use systems viz., an agricultural system which includes maize, groundnut and ragi land-use systems, the horticultural system which include coconut, arecanut and pomegranate land-use systems, scrubby land and currently fallow land use from different depths $(0-20 \mathrm{~cm}, 20-40 \mathrm{~cm}$ and 40-60 cm). these soil samples were analysed for different carbon fractions.

\section{Results and Discussion}

At surface layer significantly higher mean of PDOC content was observed in arecanut landuse system $\left(14.20 \mathrm{~g} \mathrm{~kg}^{-1}\right)$ which is followed by coconut land-use system $\left(13.10 \mathrm{~g} \mathrm{~kg}^{-1}\right)$ and lowest organic carbon content of $7.07 \mathrm{~g} \mathrm{~kg}^{-1}$ was observed in maize land-use system (Table 1). At 20 to $40 \mathrm{~cm}$ and 40 to $60 \mathrm{~cm}$, arecanut land-use system recorded a significantly higher mean of PDOC content of $13.47 \mathrm{~g} \mathrm{~kg}^{-1}$ and $12.83 \mathrm{~g} \mathrm{~kg}^{-1}$, respectively. Lowest mean PDOC content was recorded under maize land-use system with $6.67 \mathrm{~g} \mathrm{~kg}^{-1}$ at 20 to $40 \mathrm{~cm}$ and $6.03 \mathrm{~g} \mathrm{~kg}^{-1}$ at 40 to $60 \mathrm{~cm}$. The higher PDOC content under horticultural crops can be associated with the large annual addition of organic matter in the form of leaf litter, longer residue time in the soil due to less soil disturbances, which consequently ends up in the accumulation of higher PDOC in these soils (Ashura, 2016). Similar result was reported by Brij et al (2012).

Arecanut land-use systems recorded significantly higher mean of PPOC content of $427.44 \mathrm{mg} \mathrm{kg}^{-1}, 421.84 \mathrm{mg} \mathrm{kg}^{-1}$ and 414.58 $\mathrm{mg} \mathrm{kg}^{-1}$ at 0 to $20 \mathrm{~cm}, 20$ to $40 \mathrm{~cm}$ and 40 to $60 \mathrm{~cm}$, respectively, which is followed by coconut land-use system $\left(418.70 \mathrm{mg} \mathrm{kg}^{-1}\right.$ at 0 $20 \mathrm{~cm}, 412.51 \mathrm{mg} \mathrm{kg}^{-1}$ at $20-40 \mathrm{~cm}$ and $405.37 \mathrm{mg} \mathrm{kg}^{-1}$ at $40-60 \mathrm{~cm}$ ) (Table 1). Significantly lower PPOC content of 348.89 $\mathrm{mg} \mathrm{kg}{ }^{-1}, 342.25 \mathrm{mg} \mathrm{kg}^{-1}$ and $335.13 \mathrm{mg} \mathrm{kg}^{-1}$ at 0 to $20 \mathrm{~cm}, 20$ to $40 \mathrm{~cm}$ and 40 to $60 \mathrm{~cm}$, respectively was observed under maize landuse system. PPOC content in the surface layer was higher as compared to the subsurface layer. Generally, PPOC is decreased with increase in depth in all the land-use systems. The difference in PPOC content among landuse systems might be due to changes management practices that have a detrimental effect on soil carbon. A low concentration of PPOC in agricultural land-use systems can be attributed to tillage practices. The cultivation period has a negative effect on labile carbon (Sharma et al., 2014).

The CWEC recorded significantly higher mean value under arecanut land-use system $(43.29 \mathrm{mg}$ $\mathrm{kg}^{-1}$ at $0-20 \mathrm{~cm}, 41.69 \mathrm{mg} \mathrm{kg}^{-1}$ at $20-40 \mathrm{~cm}$ and $39.73 \mathrm{mg} \mathrm{kg}^{-1}$ at $40-60 \mathrm{~cm}$ ) which is followed by coconut land-use system $\left(36.73 \mathrm{mg} \mathrm{kg}^{-1}\right.$ at 0 $20 \mathrm{~cm}, 35.31 \mathrm{mg} \mathrm{kg}^{-1}$ at $20-40 \mathrm{~cm}$ and $33.68 \mathrm{mg}$ $\mathrm{kg}^{-1}$ at $40-60 \mathrm{~cm}$ ) and the lowest mean value recorded under maize land-use system (16.60 $\mathrm{mg} \mathrm{kg}^{-1}$ at $0-20 \mathrm{~cm}, 15.28 \mathrm{mg} \mathrm{kg}^{-1}$ at $20-40 \mathrm{~cm}$ and $14.26 \mathrm{mg} \mathrm{kg}^{-1}$ at $40-60 \mathrm{~cm}$ ) (Table 2). The CWEC content in the surface soil layer was higher and decreased with a decrease in depth. The lower per cent of CWEC in arable land due to high evapotranspiration of soil moisture. These results are in line with the findings of Zaimenko et al., (2014). 
Table.1 Potassium dichromate oxidizable carbon and Potassium permanganate oxidizable carbon content of soils under different landuse systems of Nandipura mini-watershed of Tarikere taluk, Chikkamagaluru District

\begin{tabular}{|c|c|c|c|c|c|c|}
\hline \multirow[t]{2}{*}{ Land use system } & \multicolumn{3}{|c|}{$\begin{array}{l}\text { Potassium dichromate oxidizable carbon } \\
\text { (PDOC) }\left(\mathrm{g} \mathrm{kg}^{-1}\right)\end{array}$} & \multicolumn{3}{|c|}{$\begin{array}{l}\text { Potassium permanganate } \\
\text { oxidizable carbon } \quad\left(\text { PPOC) }\left(\mathrm{mg} \mathrm{kg}^{-1}\right)\right.\end{array}$} \\
\hline & $0-20 \mathrm{~cm}$ & $20-40 \mathrm{~cm}$ & $40-60 \mathrm{~cm}$ & $0-20 \mathrm{~cm}$ & $20-40 \mathrm{~cm}$ & $40-60 \mathrm{~cm}$ \\
\hline Arecanut & 14.20 & 13.47 & 12.83 & 427.44 & 421.84 & 414.58 \\
\hline Coconut & 13.10 & 12.50 & 11.83 & 418.70 & 412.51 & 405.37 \\
\hline Pomegranate & 9.87 & 9.30 & 8.57 & 405.68 & 397.79 & 396.41 \\
\hline Maize & 7.07 & 6.67 & 6.03 & 348.89 & 342.25 & 335.13 \\
\hline Groundnut & 8.97 & 8.13 & 7.80 & 371.21 & 364.42 & 357.34 \\
\hline Ragi & 7.43 & 7.03 & 6.43 & 359.34 & 351.80 & 347.71 \\
\hline Scrubby land & 11.10 & 10.73 & 10.07 & 383.03 & 373.93 & 367.91 \\
\hline Fallow land & 11.87 & 11.20 & 10.80 & 395.94 & 385.23 & 377.84 \\
\hline S. Em \pm & 0.27 & 0.19 & 0.24 & 4.50 & 3.64 & 4.08 \\
\hline CD at $5 \%$ & 0.82 & 0.57 & 0.73 & 13.48 & 10.90 & 12.23 \\
\hline
\end{tabular}

Table.2 Coldwater extractable carbon and Soil microbial biomass carbon content of soils under different land-use systems of

Nandipura mini-watershed of Tarikere taluk, Chikkamagaluru District

\begin{tabular}{|c|c|c|c|c|c|c|}
\hline \multirow[t]{2}{*}{ Land use system } & \multicolumn{3}{|c|}{ Cold water extractable carbon $(\mathrm{CWEC})\left(\mathrm{mg} \mathrm{kg}^{-1}\right)$} & \multicolumn{3}{|c|}{ Soil microbial biomass carbon (SMBC) $\left(\mathrm{mg} \mathrm{kg}^{-1}\right)$} \\
\hline & $0-20 \mathrm{~cm}$ & $20-40 \mathrm{~cm}$ & $40-60 \mathrm{~cm}$ & $0-20 \mathrm{~cm}$ & $20-40 \mathrm{~cm}$ & $40-60 \mathrm{~cm}$ \\
\hline Arecanut & 43.29 & 41.69 & 39.73 & 398.67 & 372.33 & 356.67 \\
\hline Coconut & 36.73 & 35.31 & 33.68 & 373.00 & 353.33 & 329.67 \\
\hline Pomegranate & 27.38 & 26.03 & 24.56 & 277.00 & 260.33 & 244.67 \\
\hline Maize & 16.60 & 15.28 & 14.26 & 206.00 & 194.33 & 176.33 \\
\hline Groundnut & 23.05 & 22.21 & 21.27 & 237.67 & 222.33 & 212.00 \\
\hline Ragi & 20.05 & 19.20 & 17.76 & 220.67 & 209.33 & 193.67 \\
\hline Scrubby land & 29.89 & 29.05 & 27.31 & 315.33 & 295.67 & 276.00 \\
\hline Fallow land & 34.01 & 31.42 & 30.51 & 349.67 & 321.33 & 296.67 \\
\hline S. Em \pm & 0.84 & 0.71 & 0.67 & 12.69 & 15.38 & 18.94 \\
\hline CD at $5 \%$ & 2.53 & 2.14 & 2.02 & 38.06 & 46.12 & 56.78 \\
\hline
\end{tabular}


Table.3 Total organic carbon, total inorganic carbon content and total carbon content of soils under different land-use systems of Nandipura mini-watershed of Tarikere taluk, Chikkamagaluru District

\begin{tabular}{|c|c|c|c|c|c|c|c|c|c|}
\hline \multirow{2}{*}{$\begin{array}{l}\text { Land use } \\
\text { system }\end{array}$} & \multicolumn{3}{|c|}{ Total organic carbon (TOC) $\left(\mathrm{g} \mathrm{kg}^{-1}\right)$} & \multicolumn{3}{|c|}{ Total inorganic carbon (TIC) $\left(\mathrm{g} \mathrm{kg}^{-1}\right)$} & \multicolumn{3}{|c|}{ Total carbon (TC) $\left(\mathrm{g} \mathrm{kg}^{-1}\right)$} \\
\hline & $0-20 \mathrm{~cm}$ & $20-40 \mathrm{~cm}$ & $40-60 \mathrm{~cm}$ & $0-20 \mathrm{~cm}$ & $20-40 \mathrm{~cm}$ & $40-60 \mathrm{~cm}$ & $0-20 \mathrm{~cm}$ & $20-40 \mathrm{~cm}$ & $40-60 \mathrm{~cm}$ \\
\hline Arecanut & 13.09 & 12.04 & 10.86 & 0.40 & 0.37 & 0.35 & 13.49 & 12.41 & 11.23 \\
\hline Coconut & 10.91 & 10.27 & 9.28 & 0.38 & 0.36 & 0.33 & 11.29 & 10.63 & 9.61 \\
\hline Pomegranate & 5.70 & 5.46 & 5.03 & 0.34 & 0.31 & 0.29 & 6.04 & 5.77 & 5.34 \\
\hline Maize & 2.11 & 1.84 & 1.31 & 0.18 & 0.18 & 0.15 & 2.29 & 3.15 & 1.46 \\
\hline Groundnut & 4.31 & 3.79 & 3.26 & 0.27 & 0.24 & 0.25 & 4.58 & 4.03 & 3.51 \\
\hline Ragi & 2.86 & 2.45 & 2.08 & 0.24 & 0.21 & 0.19 & 3.10 & 2.66 & 2.27 \\
\hline Scrubby land & 7.89 & 7.53 & 7.18 & 0.29 & 0.26 & 0.21 & 8.18 & 7.79 & 7.39 \\
\hline Fallow land & 9.15 & 8.42 & 7.90 & 0.32 & 0.29 & 0.25 & 9.47 & 8.71 & 8.14 \\
\hline S. Em \pm & 0.27 & 0.29 & 0.49 & 0.01 & 0.02 & 0.02 & 0.26 & 0.32 & 0.48 \\
\hline CD at $5 \%$ & 0.80 & 0.87 & 1.47 & 0.04 & 0.05 & 0.06 & 0.78 & 0.96 & 1.45 \\
\hline
\end{tabular}

Table.4 Carbon stock of soils under different land-use systems of Nandipura mini-watershed of Tarikere taluk, Chikkamagaluru District

\begin{tabular}{|c|c|c|c|}
\hline \multirow{2}{*}{ Land use system } & \multicolumn{3}{|c|}{ Carbon stock $(\mathbf{t}$ C ha-1 } \\
\hline & $\mathbf{0 - 2 0} \mathbf{c m}$ & $\mathbf{2 0 - 4 0} \mathbf{~ c m}$ & $\mathbf{4 0 - 6 0} \mathbf{~ c m}$ \\
\hline Arecanut & 30.95 & 29.71 & 28.66 \\
\hline Coconut & 29.26 & 28.34 & 27.14 \\
\hline Pomegranate & 22.50 & 21.52 & 20.05 \\
\hline Maize & 17.29 & 16.49 & 15.16 \\
\hline Groundnut & 21.28 & 19.58 & 19.13 \\
\hline Ragi & 17.99 & 17.26 & 16.00 \\
\hline Scrubby land & 25.96 & 25.39 & 24.01 \\
\hline Fallow land & 27.53 & 26.44 & 25.78 \\
\hline S. Em \pm & 0.61 & 0.45 & 0.56 \\
\hline CD at 5\% & 1.82 & 1.34 & 1.68 \\
\hline
\end{tabular}


At surface layer, SMBC recorded significantly higher mean value under arecanut land-use system (398.67 $\mathrm{mg} \mathrm{kg}^{-1}$ ) which is followed by coconut land-use system (373.00 mg kg-1) and maize land-use system was lowest which recorded a value of 206.00 $\mathrm{mg} \mathrm{kg}^{-1}$ (Table 2). At 20 to $40 \mathrm{~cm}$ and 40 to 60 $\mathrm{cm}$, arecanut land-use system recorded significantly higher mean SMBC content of $372.33 \mathrm{mg} \mathrm{kg}{ }^{-1}$ and $356.67 \mathrm{mg} \mathrm{kg}^{-1}$, respectively. Lowest mean SMBC content was recorded under maize land-use system with $194.33 \mathrm{mg} \mathrm{kg}^{-1}$ at 20 to $40 \mathrm{~cm}$ and $176.33 \mathrm{mg} \mathrm{kg}^{-1}$ at 40 to $60 \mathrm{~cm}$. SMBC was decreased with increase in depth in all the land-use systems studied in the Nandipura mini-watershed. The application of manure had a positive effect on soil organic matter content, which in turn decides the SMBC (Asha, 2016). These findings are consistent with previous studies by Pramod et al., (2012), who reported higher MBC content in soils under forests $\left(430.7 \mu \mathrm{g} \mathrm{g}^{-1}\right)$ followed by a horticulture system (355.5 $\left.\mu \mathrm{g} \mathrm{g}^{-1}\right)$ and agriculture land use $\left(257.8 \mu \mathrm{g} \mathrm{g}^{-1}\right)$.

Significantly higher mean value of TOC was recorded in the soil under arecanut land-use system $\left(13.09 \mathrm{~g} \mathrm{~kg}^{-1}\right.$ at $0-20 \mathrm{~cm}, 12.04 \mathrm{~g} \mathrm{~kg}^{-1}$ at $20-40 \mathrm{~cm}$ and $10.86 \mathrm{~g} \mathrm{~kg}^{-1}$ at $40-60 \mathrm{~cm}$ ) which is followed by coconut land-use system (10.91 $\mathrm{g} \mathrm{kg}^{-1}$ at $0-20 \mathrm{~cm}, 10.27 \mathrm{~g} \mathrm{~kg}^{-1}$ at $20-40$ $\mathrm{cm}$ and $9.28 \mathrm{~g} \mathrm{~kg}^{-1}$ at $40-60 \mathrm{~cm}$ ) and the lowest mean value of TOC content was recorded under maize land-use system $(2.11 \mathrm{~g}$ $\mathrm{kg}^{-1}$ at $0-20 \mathrm{~cm}, 1.84 \mathrm{~g} \mathrm{~kg}^{-1}$ at $20-40 \mathrm{~cm}$ and $1.31 \mathrm{~g} \mathrm{~kg}^{-1}$ at $40-60 \mathrm{~cm}$ ) (Table 3). The TOC content in the surface layer was higher and decreased with a decrease in depth. The variation of TOC content is due to intensive cultivation of crops which has caused 47 per cent of soil organic carbon losses in the surface layer because of the rapid decomposition of native soil organic matter (Seema, 2019).
At surface layer, TIC was significantly higher in arecanut land-use system $\left(0.40 \mathrm{~g} \mathrm{~kg}^{-1}\right)$ which is followed by coconut land-use system $\left(0.38 \mathrm{~g} \mathrm{~kg}^{-1}\right)$ and lowest in maize land-use system $\left(0.18 \mathrm{gkg}^{-1}\right)$ (Table 3). At 20 to $40 \mathrm{~cm}$ and 40 to $60 \mathrm{~cm}$, arecanut land-use system recorded significantly higher mean TIC content of $0.37 \mathrm{~g} \mathrm{~kg}^{-1}$ and $0.35 \mathrm{~g} \mathrm{~kg}^{-1}$, respectively. Lowest mean TIC content was recorded under maize land-use system with $0.18 \mathrm{~g} \mathrm{~kg}^{-1}$ at 20 to $40 \mathrm{~cm}$ and $0.15 \mathrm{~g} \mathrm{~kg}^{-1}$ at 40 to $60 \mathrm{~cm}$. TIC content decreased with increase in depth. Significantly higher TIC values were observed under the horticultural land-use system (arecanut, pomegranate and coconut). The soil $\mathrm{pH}$ is also slightly neutral under horticultural systems. And hence, soil having a small amount of calcium and magnesium carbonates. These results are similar to the findings of Venkanna et al., (2014) and Pradeepa et al., (2018).

Significantly higher mean value of TC was recorded under arecanut land-use system (13.49 $\mathrm{g} \mathrm{kg}^{-1}$ at $0-20 \mathrm{~cm}, 12.41 \mathrm{~g} \mathrm{~kg}^{-1}$ at $20-40$ $\mathrm{cm}$ and $11.23 \mathrm{~g} \mathrm{~kg}^{-1}$ at $\left.40-60 \mathrm{~cm}\right)$ which is followed by coconut land-use system $(11.29 \mathrm{~g}$ $\mathrm{kg}^{-1}$ at $0-20 \mathrm{~cm}, 10.63 \mathrm{~g} \mathrm{~kg}^{-1}$ at $20-40 \mathrm{~cm}$ and $9.61 \mathrm{~g} \mathrm{~kg}^{-1}$ at $40-60 \mathrm{~cm}$ ) and the lowest mean value of TC content was recorded under maize land-use system $\left(2.29 \mathrm{~g} \mathrm{~kg}^{-1}\right.$ at $0-20$ $\mathrm{cm}, 3.15 \mathrm{~g} \mathrm{~kg}^{-1}$ at $20-40 \mathrm{~cm}$ and $1.46 \mathrm{~g} \mathrm{~kg}^{-1}$ at $40-60 \mathrm{~cm}$ ) (Table 3). The TC content in the surface layer was higher and decreased with a decrease in depth. The higher TC content in this system might be due to higher biomass turn over as a result of the higher leaf shedding and diversity of tree species (Seema, 2019). These results are in line with the findings of Syed (2010).

At surface layer, carbon stock potential significantly higher in arecanut land-use system (30.95 t C ha-1) which is followed by coconut land-use system $\left(29.71 \mathrm{t} \mathrm{C} \mathrm{ha}^{-1}\right)$ and least was observed in maize land-use system 
(17.29 t C ha ${ }^{-1}$ ) (Table 4). At subsurface soil layer carbon stock potential under all land-use systems was found to be lower when compared to surface soil depth. At 20 to 40 $\mathrm{cm}$ and 40 to $60 \mathrm{~cm}$, arecanut land-use system recorded significantly higher mean carbon stock potential of $29.71 \mathrm{t} \mathrm{C} \mathrm{ha}^{-1}$ and $28.66 \mathrm{t} \mathrm{C}$ $\mathrm{ha}^{-1}$, respectively. Lowest mean carbon stock potential was recorded under maize land-use system with $16.49 \mathrm{t} \mathrm{C} \mathrm{ha}^{-1}$ at 20 to $40 \mathrm{~cm}$ and $15.16 \mathrm{t} \mathrm{C} \mathrm{ha}^{-1}$ at 40 to $60 \mathrm{~cm}$. Higher carbon stocks under plantation trees indicate higher organic carbon turnover through the decomposition of leaf litter (Asha, 2016). Roy et al., (2010) also found an increase in organic carbon status with the addition of organic matter through leaf litter in the forest land-use system.

In conclusion the significantly higher carbon fractions were recorded in horticultural landuse systems (arecanut land-use system) and lower carbon fractions was recorded under agricultural land-use systems (maize land-use system). Horticultural land-use systems increased carbon in the soil followed by agricultural land-use systems.

\section{References}

Asha, S. S., 2016, impact of land use systems on nutrient and carbon distribution in soils of Thirthahalli Taluk, Shivamogga district. M.Sc. (Agri.) Thesis, Univ. Agric. Horti. Sci., Shivamogga, Karnataka, India.

Ashura, A. D., 2016, Soil aggregation and organic carbon fractions under different land uses in submontane Punjab. M.Sc. (Agri.) Thesis, Punjab Agric. Univ., Ludhaina, Punjab, India.

Brij, L. L., Manish, K. P., Pramod, J. and Biswas, A. K., 2012, Soil organic carbon pools and indices under different land use system in Vertisols of Central India. J. Indian Soc. Soil
Sci., 60(2): 125-131.

Pradeepa, K. L., Ravikumar, D., Chidanandappa, H. M., Jadegowda, M. and Shoba, S., 2018, Impact of land use on soil organic carbon fraction in Central parts of Western Ghat of Virajpet taluk. J. Farm Sci. Spl. Issue, 31(5):555-558.

Pramod, J., Arpan, D., Brij, L. L., Biswas, A. K., Singh, M., Reddy, K. S. and Rao, A. S., 2012, Soil carbon pools, mineralization and fluxes associated with land use change in vertisols of central India. Natl Acad Sci Lett., 35: 475-83.

Roy, P. K., Samal, N. R., Roy, M. B. and Mazumdar, A., 2010, Soilcarbon and nutrient accumulation under forest plantations in Jharkhand state of India.Clean - Soil, Air, Water. 38(8): 706-712.

Seema, A. J., 2019, Assessment of soil organic carbon fractions in soils under different land use systems of Somawarpet taluk, Kodagu district. $M$. Sc. (Agri.) Thesis, Univ. Agric. Horti. Sci., Shivamogga, Karnataka, India.

Sharma, V., Shabeer, H., Sharma, K. R. and Vivak M. A., 2014, Labile carbon pools and soil organic carbon stocks in the Foothill Himalayas under different land use systems. Geoderma, 234: 8187.

Swarup, A., Manna, M. C. and Singh, G. B., 2000, Impact of land use and management practiced on organic carbon dynamics in soils of India. In: Lal. (Ed.), Advances in Soil Science Global Climate Change and Tropical Ecosystem. CRC Lewis, Boca Raton, $F L$, pp. 261-281.

Syed, W. J., 2010, Forms and status of nutrients in different land use systems of alfisols. M.Sc. (Agri). Thesis, submitted to Univ. Agric. Sci., Bangalore. 
Venkanna, K., Mandal U. K., Solomon Raju, A. J., Sharma, K. L., Adake, R. V., Pushpanjali., Reddy, B. S., Masane, R. N., Venkataravamma, K. and Pedubabu, B., 2014, Carbon stock in major soil types and land use systems in Semiarid Tropical Region of Southern India. Curr. Sci., 106(4): 604-
611.

Zaimenko, N. V., Dziuba, O. I. and Bedernichek, T. Y., 2014, Total and water soluble organic matter content in soil under various methods of forestry. ISSN 1605-6574.

\section{How to cite this article:}

Jahnavi Katti, K. T. Gurumurthy, D. Ravikumar and Vageesh, T. S. 2020. Carbon Dynamics under Different Land-Use Systems of Nandipura Mini-Watershed of Chikkamagaluru District, Karnataka, India. Int.J.Curr.Microbiol.App.Sci. 9(10): 3968-3974. doi: https://doi.org/10.20546/ijcmas.2020.910.456 